\title{
MECHANICAL PROPERTIES OF GRAPHENE-NANOPARTICLE AND CARBON-NANOTUBE-REINFORCED PE-MATRIX NANOCOMPOSITES
}

\author{
MEHANSKE LASTNOSTI NANODELCEV GRAFENA IN \\ OGLJIKOVIH NANOCEVČIC KOT OJAČITVE V POLIETILENSKI \\ MATRICI NANOKOMPOZITOV
}

\author{
Mehmet Akif Erden ${ }^{*}$, Yasin Akgul'2, Ozge Kayabas', Hayrettin Ahlatci², \\ Kerim Cetinkaya ${ }^{3}$, Fatih Huzeyfe Ozturk ${ }^{3}$ \\ ${ }^{1}$ Karabuk University, Manufacturing Engineering, 78050 Karabuk Merkez, Turkey \\ ${ }^{2}$ Karabuk University, Metallurgical and Materials Engineering, 78050 Karabuk Merkez, Turkey \\ ${ }^{3}$ Karabuk University, Industrial Design Engineering, 78050 Karabuk Merkez, Turkey \\ Prejem rokopisa - received: 2019-04-01; sprejem za objavo - accepted for publication: 2019-05-17
}

doi:10.17222/mit.2019.071

\begin{abstract}
In this study, graphene-nanoplatelet (GNP) and carbon-nanotube (CNT) reinforced nanocomposites were produced with pressure molding. 1 w/\% of GNPs and $1 w / \%$ of CNTs were separately added to a polyethylene (PE) matrix and 0.5 w $/ \%$ of both reinforcements was also jointly added to the PE matrix. In this manner, the effects of GNPs and CNTs on the mechanical properties of PE were compared and the synergistic effect was investigated. In order to examine the mechanical properties, a tensile test, a hardness test and a wear test were applied to the produced samples. Also, fracture surfaces and wear surfaces were investigated with a scanning electron microscope (SEM). It was observed that the graphene was distributed homogeneously in the polyethylene matrix. Thus, the GNP-containing samples showed better mechanical properties than the CNT-containing samples.

Keywords: polymer-matrix composites, compression molding, high-density polyethylene, graphene, carbon nanotube

V študiji avtorji opisujejo izdelavo polimernih kompozitov, ojačanih z grafenskimi nanoploščicami (GNPs) in ogljikovimi nanocevkami (CNTs). Postopek izdelave je potekal z oblikovanjem v kovinskem modelu pod tlakom. V prvo polietilensko (PE) matrico so dodali 1 mas. \% GNPs, v drugo 1 mas. \% CNTs in v tretjo po 0,5 mas. \% obeh ojačitvenih faz. Nato so določili mehanske lastnosti izdelanih kompozitov in ugotavljali vpliv dodatka GNPs in CNTs ter raziskovali sinergijski učinek obeh. V ta namen so na izdelanih preizkušancih izvedli natezni preizkus, meritve trdote in odpornosti proti obrabi. Prelomne in obrabne površine so prav tako pregledali pod vrstičnim elektronskim mikroskopom (SEM). Rezultati raziskave so pokazali, da je grafen enakomerno porazdeljen po PE matrici. Zato so imeli vzorci, ki so vsebovali GNPs boljše mehanske lastnosti kot vzorci, ki so vsebovali CNTs.

Ključne besede: kompoziti s polimerno matrico, oblikovanje pod tlakom, polietilen z visoko gostoto, grafen, ogljikove nanocevke
\end{abstract}

\section{INTRODUCTION}

Thermoset resins are widely used in commercial applications in the fabrication of polymer-matrix composites. However, these materials have disadvantages such as the lack of recycling and a low shaping capacity. ${ }^{1}$ For this reason, commercial applications involving thermoplastic-matrix composites have been started in recent years. Therefore, many academic studies on the subject have been conducted. ${ }^{2}$ Nano-sized reinforcements have become popular for these thermoplastic composites because they allow us to change the properties of the matrix with very low loadings $(<2 \phi / \%){ }^{3}$

Graphene nanoplatelets (GNPs) and carbon nanotubes (CNTs) are promising nano-sized reinforcement materials due to their unique mechanical properties. ${ }^{4}$ GNPs, which are two-dimensional materials with a

*Corresponding author's e-mail:

makiferden@karabuk.edu.tr (Mehmet Akif Erden) one-atom-thick planar sheet of $\mathrm{sp}^{2}$-bonded carbon atoms, are densely packed in a honeycomb crystal lattice. ${ }^{5}$ They have high Young's modulus (1 TPa) and high fracture strength $(125 \mathrm{GPa}){ }^{6} \mathrm{CNTs}$, which were discovered by $\mathrm{K}$. Lau et al., ${ }^{7}$ have diameters ranging from $1 \mathrm{~nm}$ to 100 $\mathrm{nm}$, lengths of up to millimeters and a density ${ }^{8}$ of 1.3 $\mathrm{g} / \mathrm{cm}^{3}$. CNTs are created by rolling a single graphene sheet seamlessly to form a cylinder. ${ }^{9}$ Their ultimate break stress is nearly $200 \mathrm{GPa}$ and elastic modulus is 1 TPa. ${ }^{10}$

A HDPE (high-density polyethylene)/GNP blend was mixed homogeneously by A. J. Bourque et al. ${ }^{11}$ using a solution during the blending. Mechanical properties of the GNP-HDPE composites were significantly improved up to $15 w / \%$ GNP loadings. W. Tang et al. ${ }^{12}$ fabricated HDPE/CNT composites with (0, 1, 3 and 5) \% nanotube amounts. It was found that the stiffness and peak load increase with an increasing MWCNT amount. For another study, HDPE/CNT composites were produced by 
S. Kanagaraj et al. ${ }^{13}$ via injection molding. Results showed that although the melting point and oxidation temperature of the composites were not affected by the addition of CNTs, the crystallinity was increased.

In this study, PE-matrix nanocomposites were fabricated with compression molding. The effects of GNPs and CNTs on the mechanical and tribological properties of PE were compared. Also, the synergistic effect of these reinforcements was investigated.

\section{EXPERIMENTAL PART}

The graphene nanoparticles used in this study had a surface area of $750 \mathrm{~m}^{2} / \mathrm{g}$ and a thickness of 5-8 nm while the multi-walled carbon nanotubes had a thickness of 9.5 $\mathrm{nm}$ and a surface area of $250 \mathrm{~m}^{2} / \mathrm{g}$. Carbonaceous reinforcements were purchased from Nanografi (Turkey). High-density polyethylene (HDPE), used as the matrix in the study, had a density of $0.91 \mathrm{~g} / \mathrm{cm}^{3}$ and was supplied from PETKIM.

The granular polymer and reinforcements (in powder form) were being stirred in a turbula mixer for 1 hour. In this step, the granular polymer used as the matrix material and the nanopowders used as the reinforcement material were solid, so the mixing process can be called solid-solid mixing. The mixture was filled into a mold and the mold was heated to $170{ }^{\circ} \mathrm{C}$. This mold temperature was then kept constant for 5 min to provide for homogenous heating of the mold. Then, pressing was applied at $20 \mathrm{MPa}$. The mold was cooled in air and the samples (Figure 1) were removed.

Tensile tests were conducted with Shimadzu Trapezium Single with a $50-\mathrm{kN}$ capacity at a $5-\mathrm{mm} / \mathrm{min}$ speed. A UTS-10 Tribometer test device was used for the corresponding wear tests. During a wear test, an AISI 52100 steel ball was used and the stroke distance was kept at $10 \mathrm{~mm}$. The applied loads were 30 Nand $60 \mathrm{~N}$. The Brinell hardness test was performed on a QNESS Q250M hardness measurement device under a 2500-g load. In order to determine the hardness of the material, five measurements were taken for each sample. The fractured surfaces and wear surfaces were examined with a Zeiss UltraPlus SEM after coating the samples with the Au-Pd alloy.

\section{RESULTS AND DISCUSSION}

Stress-strain graphs of the samples are shown in Figure 2. It can be concluded that both carbon-based reinforcements increased the strength of pure PE. Comparing GNPs with CNTs, it was observed that GNPs increased the tensile strength more than CNTs.

Figure 3c shows that carbon nanoparticles agglomerated in the samples containing CNTs according to the fracture surfaces. This adversely affected the mechanical properties. This can be attributed to the facts that the samples were prepared with solid-solid mixing and the

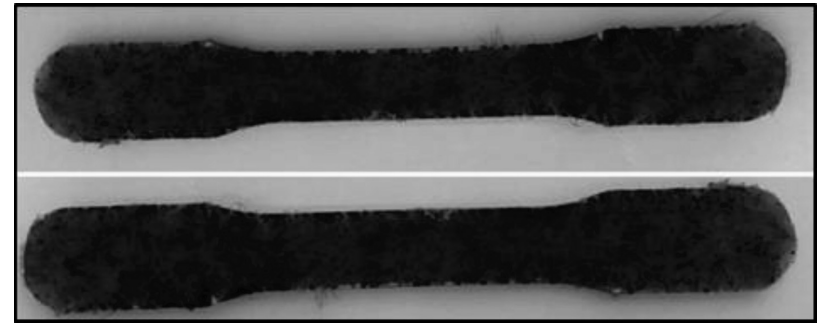

Figure 1: Produced samples

CNTs agglomerated due to their van der Vaals bonds. ${ }^{14}$ From Figure 3a, it is clear that there is no porosity or homogenous distribution in the PE/GNP sample compared to the other samples. The reason for this is the fact that graphene has weaker van der Vaals bonds, so the GNPs show less agglomeration in the matrix. Also, it can be said that there are some porosities, which cause a decrease in the mechanical properties of the matrix of the PE/GNPs+CNTs sample (Figure 3b).

As shown in Table 1, although carbon-based reinforcements increased the strength of PE, they caused a decrease in the elongation values of PE. This is because
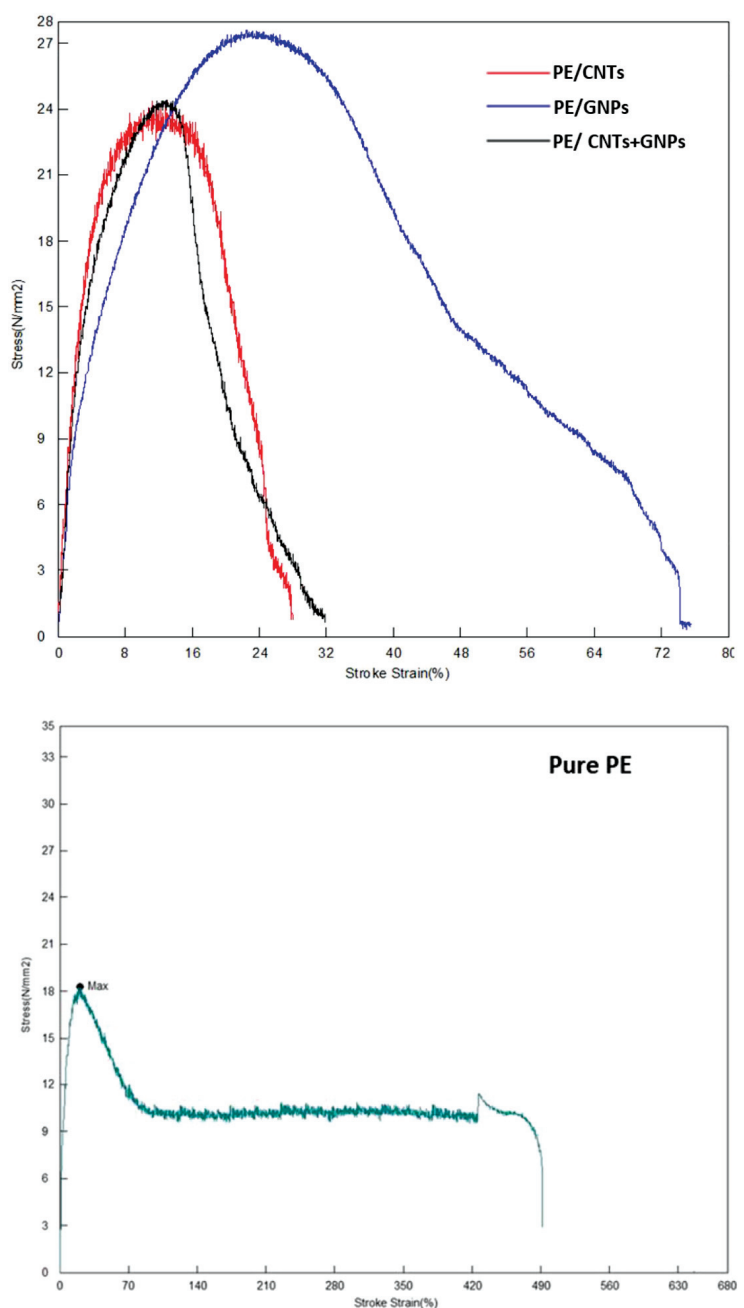

Figure 2: Tensile properties of the composites and pure HDPE 

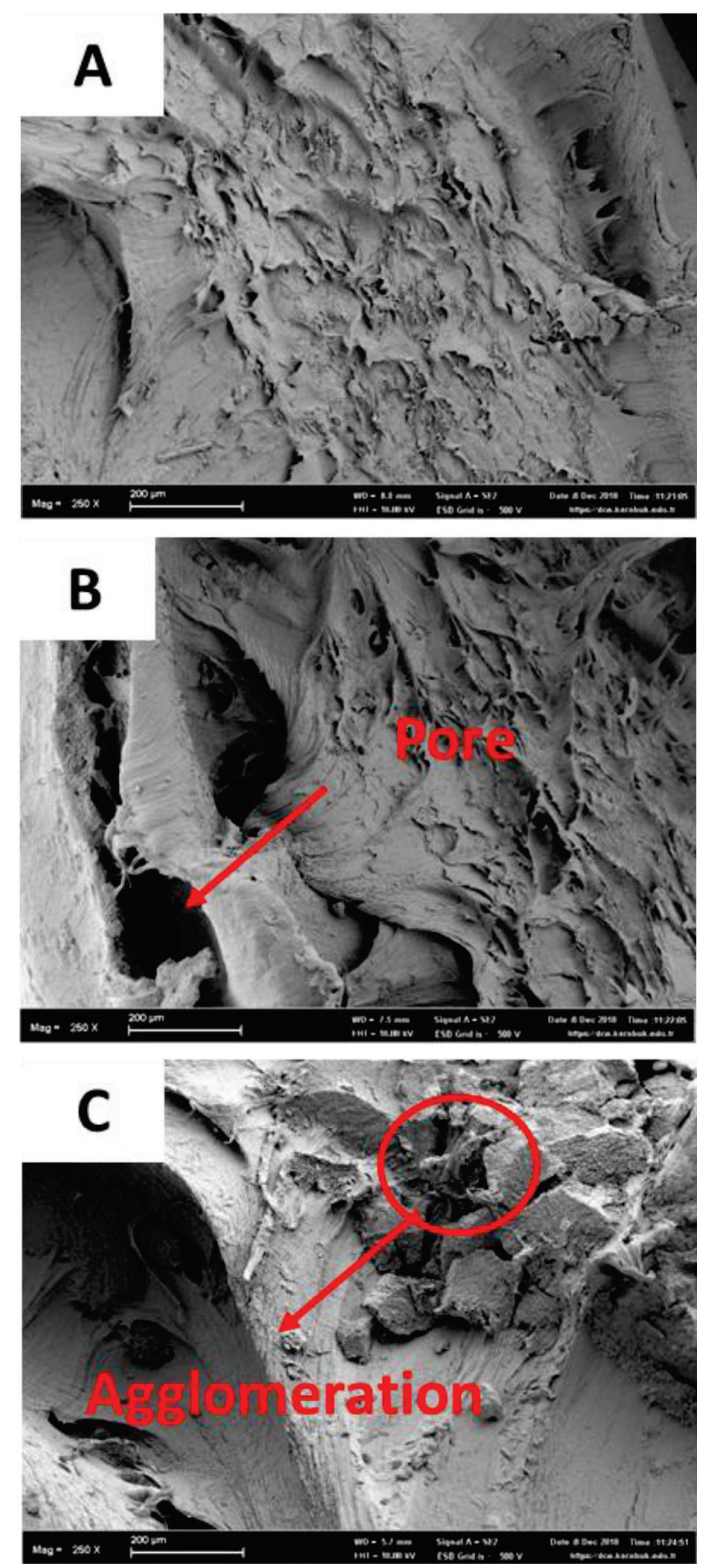

Figure 3: Fracture surfaces of: a) PE/GNPs, b) PE/CNTs+GNPs, c) $\mathrm{PE} / \mathrm{CNTs}$

when the material is under load, the nanoparticles restrict the movement of the polymer chains and cause the load to be transferred from the polymer to these nanofillers. ${ }^{15}$ As mentioned above, there are less agglomeration and fewer pore defects in the structure of the PE/GNP sample. Thus, the PE/GNP sample has higher elongation values compared to the other composites.

Table 1: Mechanical properties of the samples

\begin{tabular}{|c|c|c|c|}
\hline Sample & $\begin{array}{c}\text { Ultimate tensile } \\
\text { strength (MPa) }\end{array}$ & $\begin{array}{c}\text { Elongation } \\
(\%)\end{array}$ & $\begin{array}{c}\text { Hardness } \\
(\text { Brinell) }\end{array}$ \\
\hline $\mathrm{PE}$ & 18 & 490 & $6.7 \pm .0 .48$ \\
\hline $\mathrm{PE} / \mathrm{CNT}$ & 23 & 28 & $7.2 \pm 0.30$ \\
\hline $\mathrm{PE} / \mathrm{GNP}$ & 28 & 75 & $7.5 \pm 0.36$ \\
\hline PE/CNT+GNP & 24 & 32 & $6.8 \pm 0.25$ \\
\hline
\end{tabular}
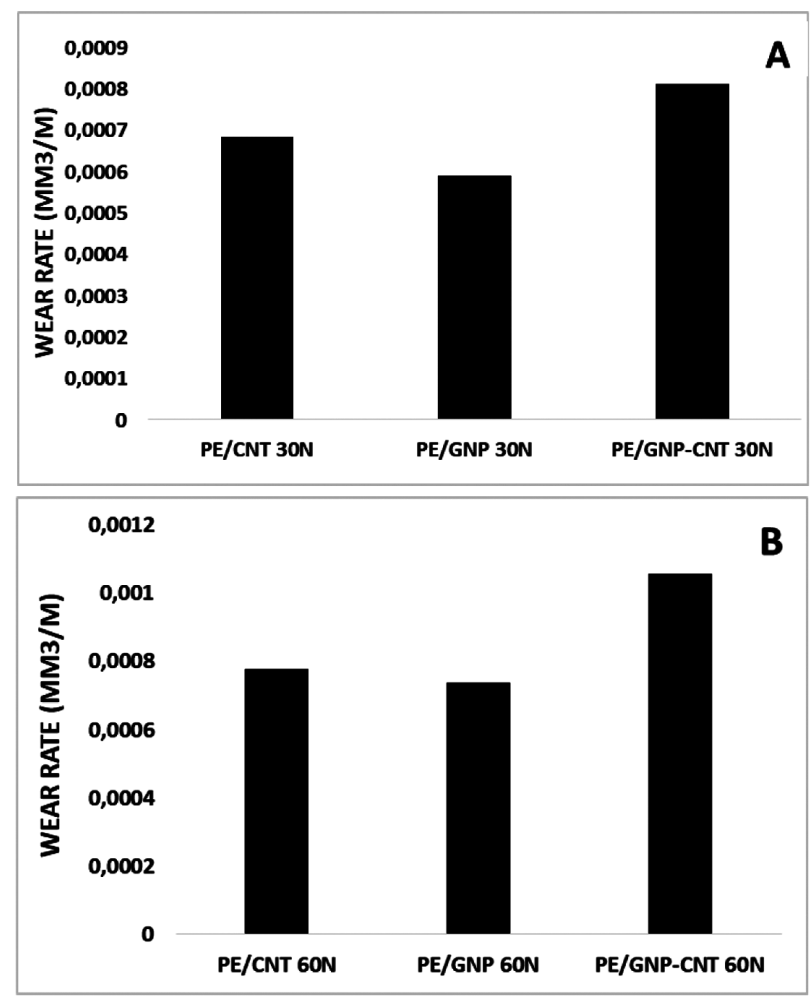

Figure 4: Wear rates of the samples under: a) 30-N load, b) 60-N load
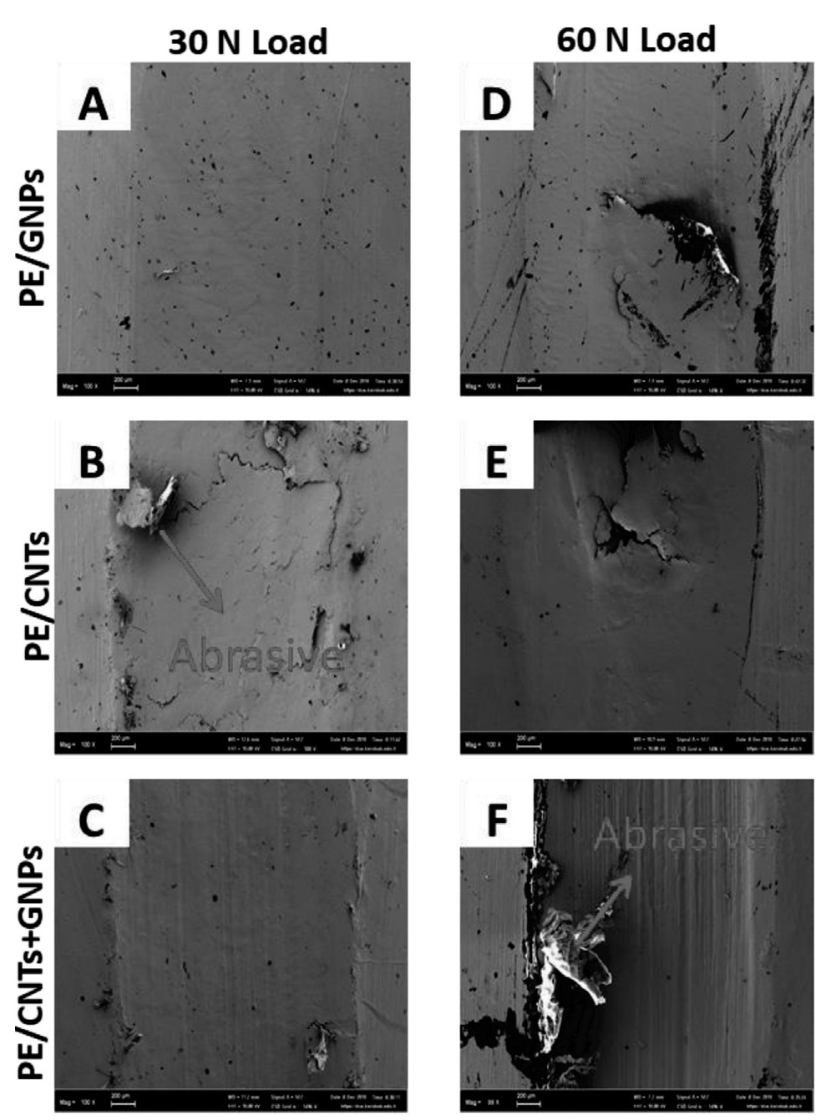

Figure 5: SEM images of worn surfaces of the samples 
The hardness results for the samples are given in Table 1. The addition of $1 w / \%$ of GNPs to the matrix increased the hardness value of polyethylene by $12 \%$ while the addition of $1 \mathrm{w} / \%$ of CNTs to the matrix increased the hardness value of polyethylene by $7.5 \%$. This increase in the hardness can be explained with the addition of harder particles to the matrix. ${ }^{16}$ The hardness of the sample containing $0.5 \%$ of GNPs and $0.5 \%$ of CNTs is almost equal to the hardness value of pure polyethylene due to the agglomeration of CNTs and the porosity in the matrix. Wear rates of the composites under 30-N and 60-N loads are given in Figure 4. The results of the wear and hardness tests were directly proportional. This can be explained with the fact that as the hardness of the material increases, the resistance to abrasion increases. ${ }^{17}$ The wear rate of PE/GNPs with the best abrasion resistance was $5.9 \mathrm{~mm}^{3} / 104 \mathrm{~m}$ at the $30-\mathrm{N}$ load. However, this value was increased to $7.3 \mathrm{~mm}^{3} / 104$ $\mathrm{m}$ for the $60-\mathrm{N}$ load. The increase in the wear rate was observed for all the samples as a result of the increased load. This can be attributed to the fact that repeated higher loads on the surfaces of samples can form higher friction forces. ${ }^{18}$

As seen in Figure 5, as a result of the wear test, there are pieces ruptured from the samples. Therefore, it can be said that the abrasive-wear mechanism was formed. When the load was increased to $60 \mathrm{~N}$, parallel scratches were formed on the sample. However, the resulting straches are more clearly seen for the PE/CNTs+GNPs sample. The reason for this is that wider scratches can be seen on the materials with a low wear resistance. ${ }^{19}$ This is also indicative of the abrasive-wear mechanism.

\section{CONCLUSIONS}

In this study, carbon-nanoparticle-reinforced polyethylene-matrix nanocomposites were successfully produced with pressure molding. The results of the characterization of the produced samples can be summarized as follows:

The additions of GNPs and CNTs led to an increase in the tensile strength of HPDE. However, the comparison showed a greater increase in GNPs/PE compared to CNTs/PE. The reason for this is that during solid-solid mixing, CNTs form clumps due to van der Waals bonds. Carbon nanoparticles were found to be agglomerated in the samples containing CNTs when fracture surfaces were examined. GNPs showed a more homogenous distribution in the PE matrix than CNTs.

The addition of $1 \%$ of GNPs and $1 \%$ CNTs to the PE matrix increased the hardness of pure polyethylene by $12 \%$ and $7.5 \%$, respectively.

With regard to their wear resistance, the samples can be listed in the following sequence: PE/GNPs, PE/CNTs, $\mathrm{PE} / \mathrm{GNPs}-\mathrm{CNTs}$, the wear resistance being in proportion to their hardness. The abrasive-wear mechanism was the dominant mechanism for all the samples.
As a result, the GNP addition to the PE matrix had a better effect on mechanical properties than the addition of CNTs. It is thought that mixing PE and CNTs in a solution makes CNTs more effective than solid-solid mixing ${ }^{20}$. It is proposed that the produced graphene-containing nanocomposites can be used for corrosionresistant and wear-resistant surfaces.

\section{Acknowledgment}

The authors are indebted to Mr. Salih Bektas and Mr. Ahmet Tanriverdi for the fabrication of the samples.

\section{REFERENCES}

${ }^{1}$ D. V. Rosato, M. G. Rosato, Injection molding handbook, Springer Science \& Business Media, 2012

${ }^{2}$ S.-S. Yao, F.-L. Jin, K. Y. Rhee, D. Hui, S.-J. Park, Recent advances in carbon-fiber-reinforced thermoplastic composites: a review, Compos. Part B: Eng., 142 (2018), 241-250

${ }^{3}$ T. Ramanathan A. A. Abdala, S. Stankovich, D. A. Dikin, M. Herrera-Alonso, R. D. Piner, D. H. Adamson, H. C. Schniepp, X. Chen, R. S. Ruoff, Functionalized graphene sheets for polymer nanocomposites, Nat. Nanotechnol., 3 (2008), 327

${ }^{4}$ T. Batakliev, I. Petrova-Doycheva, V. Angelov, V. Georgiev, E. Ivanov, R. Kotsilkova, M. Casa, C. Cirillo, R. Adami, M. Sarno, Effects of graphene nanoplatelets and multiwall carbon nanotubes on the structure and mechanical properties of poly(lactic acid) composites: A comparative study, Appl. Sci., 9 (2019), 469

${ }^{5}$ T. Kuilla, S. Bhadra, D. Yao, N. H. Kim, S. Bose, J. H. Lee, Recent advances in graphene based polymer composites, Prog. Polym. Sci., 35 (2010), 1350-1375

${ }^{6}$ J. Wang, Z. Li, G. Fan, H. Pan, Z. Chen, D. Zhang, Reinforcement with graphene nanosheets in aluminum matrix composites, Scr. Mater., 66 (2012), 594-597

${ }^{7}$ K. Lau, C. Gu, D. Hui, A critical review on nanotube and nanotube/nanoclay related polymer composite materials, Compos. Part B: Eng., 37 (2006), 425-436

${ }^{8}$ J. N. Coleman, U. Khan, W. J. Blau, Y. K. Gun'ko, Small but strong: a review of the mechanical properties of carbon nanotube-polymer composites, Carbon, 44 (2006), 1624-1652

${ }^{9}$ K. M. Liew, Z. X. Lei, L. W. Zhang, Mechanical analysis of functionally graded carbon nanotube reinforced composites: a review, Compos. Struct., 120 (2015), 90-97

${ }^{10}$ R. Andrews, M. C. Weisenberger, Carbon nanotube polymer composites, Curr. Opin. Solid State Mater. Sci., 8 (2004), 31-37

${ }^{11}$ A. J. Bourque, C. R. Locker, A. H. Tsou, M. Vadlamudi, Nucleation and mechanical enhancements in polyethylene-graphene nanoplate composites, Polymer, 99 (2016), 263-272

${ }^{12}$ W. Tang, M. H. Santare, S. G. Advani, Melt processing and mechanical property characterization of multi-walled carbon nanotube/high density polyethylene (MWNT/HDPE) composite films, Carbon, 41 (2003), 2779-2785

${ }^{13}$ S. Kanagaraj, F. R. Varanda, T. V. Zhil'tsova, M. S. Oliveira, J. A. Simões, Mechanical properties of high density polyethylene/carbon nanotube composites, Compos. Sci. Technol., 67 (2007), 3071-3077

${ }^{14}$ M. E. Turan, Y. Sun, Y. Akgul, Y. Turen, H. Ahlatci, The effect of GNPs on wear and corrosion behaviors of pure magnesium, J. Alloys Compd., 724 (2017), 14-23

${ }^{15}$ J. Bian, G. Wang, H. L. Lin, X. Zhou, Z. J. Wang, W. Q. Xiao, X. W. Zhao, HDPE composites strengthened-toughened synergistically by 1-aspartic acid functionalized graphene/carbon nanotubes hybrid nanomaterials, J. Appl. Polym. Sci., 134 (2017), 45055 
${ }^{16}$ M. E. Turan, Y. Sun, Y. Akgul, Improved wear properties of magnesium matrix composite with the addition of fullerene using semi powder metallurgy, Fuller. Nanotub. Carbon Nanostructures, 26 (2018), 130-136

${ }^{17}$ M. E. Turan, Y. Sun, Y. Akgul, Mechanical, tribological and corrosion properties of fullerene reinforced magnesium matrix composites fabricated by semi powder metallurgy, J. Alloys Compd., 740 (2018), 1149-1158

${ }^{18}$ M. E. Turan, Y. Sun, F. Aydın, Y. Akgul, Influence of multi-wall carbon nanotube content on dry and corrosive wear performances of pure magnesium, J. Compos. Mater., 52 (2018), 3127-3135

${ }^{19}$ A. Dasari, Z.-Z. Yu, Y.-W. Mai, Fundamental aspects and recent progress on wear/scratch damage in polymer nanocomposites, Mater. Sci. Eng. R Rep., 63 (2009), 31-80

${ }^{20}$ G. Mittal, V. Dhand, K. Y. Rhee, S.-J. Park, W. R. Lee, A review on carbon nanotubes and graphene as fillers in reinforced polymer nanocomposites, J. Ind. Eng. Chem., 21 (2015), 11-25 